\title{
Can predator avoidance explain varying overwintering depth of Calanus in different oceanic water masses?
}

\author{
Trine Dale $^{1, *}$, Espen Bagøien ${ }^{1}$, Webjørn Melle $^{2}$, Stein Kaartvedt ${ }^{1}$ \\ ${ }^{1}$ Department of Biology, University of Oslo, PO Box 1064 Blindern, N-0316 Oslo, Norway \\ ${ }^{2}$ Institute of Marine Research, PO Box 1870 Nordnes, N-5024 Bergen, Norway
}

\begin{abstract}
Distributions of overwintering Calanus spp. in the upper $1000 \mathrm{~m}$ in the Norwegian and Greenland Seas were studied in relation to hydrography, invertebrate predators and acoustic scattering layers $(38 \mathrm{kHz})$. C. finmarchicus was concentrated deepest in the Atlantic domain, inhabiting the Arctic Intermediate Water (AIW) below the Atlantic Water (AW). It was less deeply distributed in the Arctic domain, where AIW reached the surface. The temperature of the overwintering habitats was mainly between -0.5 and $+0.5^{\circ} \mathrm{C}$, irrespective of region and overwintering depth. The distributions of invertebrate predators such as chaetognaths and the carnivorous copepods Euchaeta spp. and Chiridius sp. provided no explanation for the varying vertical distributions of $C$. finmarchicus. A conspicuous coupling between the level of acoustic backscattering $(38 \mathrm{kHz})$ and the type of water mass (i.e. AW or AIW) was found. High acoustic backscattering, which we ascribe to planktivorous mesopelagic fishes, was confined to the relatively warm AW. The colder AIW was almost devoid of backscattering. Thus $C$. finmarchicus appear to overwinter in waters with a low abundance of planktivorous fish in all parts of the ocean. Since temperature and predator distribution as revealed by acoustics were closely coupled, predator avoidance is an altemative explanation to metabolically motivated temperature preference in Calanus' choice of overwintering depth.
\end{abstract}

KEY WORDS: Calanus - Overwintering · Acoustic scattering layers - Mesopelagic fish - Invertebrate predators $\cdot$ Temperature

\section{INTRODUCTION}

The oceanic copepods Calanus finmarchicus, C. glacialis and C. hyperboreus (Østvedt 1955, Conover 1988) are distributed both in the eastern and western part of the North Atlantic (Conover 1988). Calanus has adapted to long periods of food shortage, typical of waters at temperate and high latitudes, by entering a resting phase with arrested development and reduced respiration in deep waters during winter (Sømme 1934, Marshall \& Orr 1955, Østvedt 1955, Hirche 1983, Conover 1988, Miller et al. 1991). C. finmarchicus and C. glacialis primarily overwinter as stage $\mathrm{CIV}$ and $\mathrm{CV}$, and $C$. hyperboreus as stage $\mathrm{CIII}$ to $\mathrm{CV}$ (Conover

•E-mail: trine.dale@bio.uio.no
1988). Nevertheless, in the North Atlantic there are great differences between overwintering habitats of $C$. finmarchicus, spanning from surface waters to depths of $2000 \mathrm{~m}$, and temperatures from -1 to $+11^{\circ} \mathrm{C}$ (Kaartvedt 1996 and references therein). In the northeast Atlantic, C. finmarchicus overwinters at different depths in different water masses. At the Atlantic side of the Arctic front, overwintering $C$. finmarchicus appears to be centred between 500 and $1500 \mathrm{~m}$, while it mostly inhabits the upper 200 to $300 \mathrm{~m}$ in the Greenland Sea Gyre (Østvedt 1955, Hirche 1991, Richter $1994,1995)$. The observed variation in overwintering habitats has mainly been ascribed to physical variables, such as temperature and light (Hirche 1991, Miller et al. 1991). Respiration is temperature dependent even for Calanus in diapause (Hirche 1983), and internal energy sources, essential for development and 
maturation of gonads (Tande \& Hopkins 1981, Tande 1982), are believed to last longer at low temperatures. Still, existing data show that overwintering Calanus is flexible in its demands to the physical environment, indicating that physical characteristics may not alone shape the Calanus overwintering distributions.

Overwintering in the inactive state of diapause may reduce the probability of encounter with tactile predators (Hairston 1987, Ohman 1988). Fjord studies have suggested that planktivorous mesopelagic fish represent a serious threat to Calanus, and could thereby be an important factor in the choice of overwintering habitat (Kaartvedt 1996). Yet, there are no concurrent data on the distributions of Calanus and its potential predators in different water masses. In this investigation, we aimed to test the hypothesis that abundance of planktivorous mesopelagic fish in Atlantic Water (AW) differs from that in Arctic Intermediate Water (AIW). In that case, selection of overwintering depth based upon predator avoidance might explain differing overwintering distributions in areas dominated by different water masses. Hence, we address relations between Calanus winter distributions, physical variables, invertebrate predators, and acoustic scattering layers, assumed largely to represent planktivorous fish (Torgersen et al. 1997).

\section{MATERIALS AND METHODS}

This survey was carried out with RV 'Johan Hjort' in the Greenland and Norwegian Seas from 8 to 27 November 1995. The survey started at Bear Island and proceeded westwards along the 74 and $75^{\circ} \mathrm{N}$, later referred to as Transect 1 (Fig. 1). The cruise track turned southeast crossing the Greenland/Norwegian Sea, later referred to as Transect 2, and thereafter turned southwest along the cruise track referred to as Transect 3 (Fig. 1). All stations were ice free

Vertically stratified zooplankton samples were taken with a KIEL MULTINET $10.25 \mathrm{~m}^{2}$ mouth area, equipped with 5 nets with $180 \mu \mathrm{m}$ mesh). Standard sampling depths were $1000-800,800-600,600-400,400-200$ and 200-0 m. Samples were preserved with $4 \%$ borate-buffered formaldehyde. A hundred randomly selected Calanus were identified to stage and measured for cephalothorax length to reveal whether $C$. finmarchicus, $C$. glacialis and $C$. hyperboreus all occurred in the sample. Species separation was based upon length criteria (Unstad \& Tande 1991, Hirche et al. 1994).
If no C. glacialis were found among 100 specimens, no further measurements were made. However, if $C$. glacialis specimens were found, all individuals were measured. For samples containing more than 300 to 400 Calanus, subsamples with at least 300 individuals were identified to stage and sex.

All macrozooplankton predators sampled by the MULTINET along with Calanus spp. were counted. Euchaeta spp. were identified to stage and sex (CIV to adults), while Chiridius sp. was classified as either juveniles, adult females or males. Chaetognaths were allocated to length classes, but not identified to species. Weighted Mean Depth (WMD) for the upper $1000 \mathrm{~m}$ was calculated for each species and stage (size class).

To roughly assess the nektonic predators along the transects, acoustic backscattering was continuously recorded by a hull mounted SIMRAD EK $50038 \mathrm{kHz}$ echo sounder, Most plankters are not detected at this frequency, and the echoes largely represent planktivorous fish (Torgersen et al. 1997). Data for the upper $1000 \mathrm{~m}$ were stored by means of the Bergen Echo Integrator system (Knudsen 1990, Foote et al. 1991). The

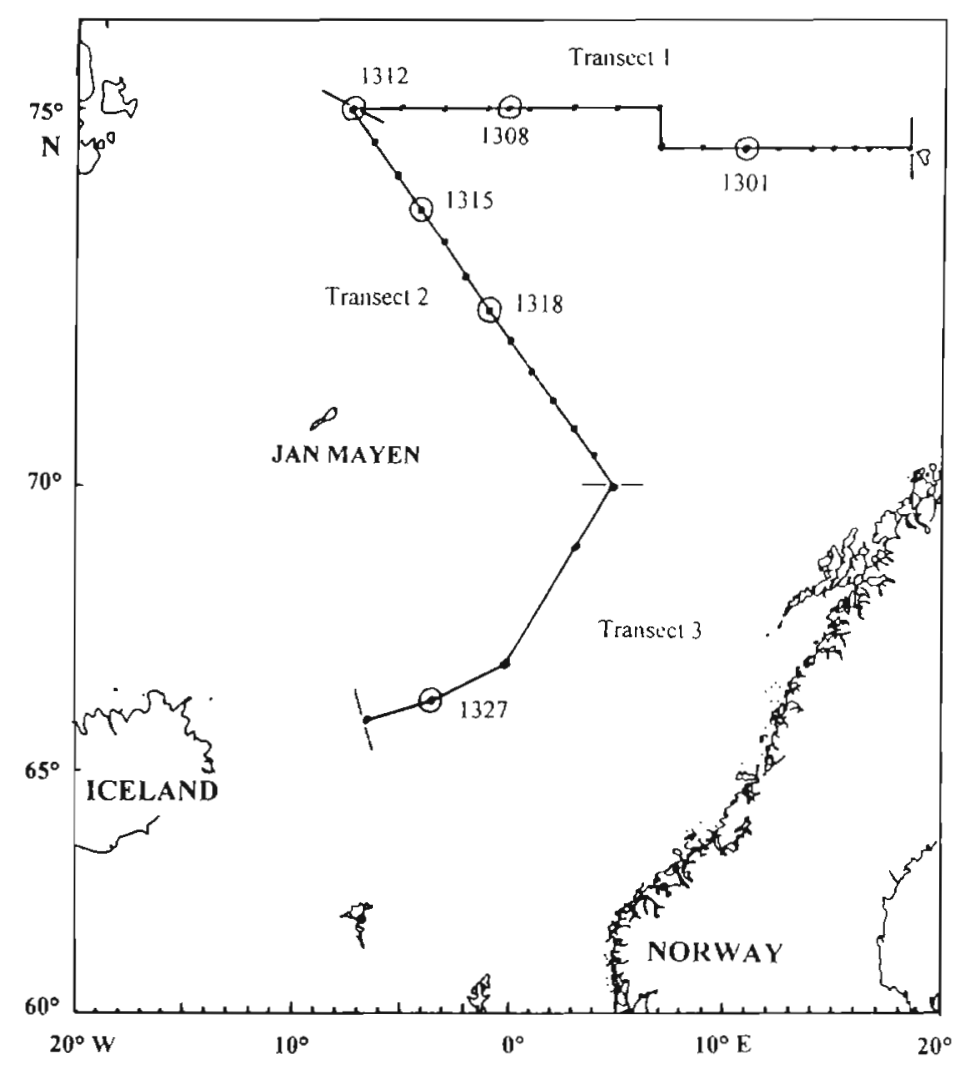

Fig. 1. Map of the study area and cruise track. CTD stations are denoted - and MULTINET stations $\odot$. Transect and station numbers are depicted and referred to in other figures and tables 
volume backscattering threshold $\left(S_{\mathrm{v}}\right)$ was set to $-84 \mathrm{~dB}$. During post-processing, acoustic area backscattering $\left(S_{\mathrm{A}}\right)$ was assigned to $12 \mathrm{~m}$ depth channels for each nautical mile $(\mathrm{nm})(1852 \mathrm{~m})$. The area backscattering $S_{\mathrm{A}}\left(\mathrm{m}^{2} \mathrm{~nm}^{-2}\right)$ for a given depth interval (Knudsen 1990 , Foote et al. 1991) relates to $S_{v}$ by the formula

$$
S_{\mathrm{A}}=4 \pi(1852)^{2} \int_{z^{1}}^{z^{2}} S_{\mathrm{v}} \mathrm{d} z
$$

where $z^{1}$ and $z^{2}$ are the limits of the vertical layer. $S_{A}$ from the upper $700 \mathrm{~m}$ was plotted using SURPHER (Golden Software, Inc.). Vertical profiles of temperature and salinity were measured with CTD.

\section{STUDY AREA}

The Norwegian and Greenland Seas can be divided into 3 domains according to the dominant water masses (Swift 1986). The eastern periphery, dominated by Atlantic waters may be termed the Atlantic domain. The western periphery, where polar waters dominate, constitutes the Polar domain, and the transition zone in the central basins the Arctic domain. All stations in this survey were located in the Allantic and Arctic domain. At the surface the warm saline Atlantic Water (AW) is separated from the cold and less saline Arctic Intermediate Water (AIW) by the Arctic front. The 2 water masses are clearly distinguished by temperature and salinity. Here the expanded definition of AW suggested by Swift 1986, which includes waters warmer than $3^{\circ} \mathrm{C}$ and more saline than 34.9 is used. AIW has a temperature between 0 and $2^{\circ} \mathrm{C}$ and salinity between 34.8 and 35.0 (Stefánsson 1962).

\section{RESULTS}

\section{Hydrography}

The first zooplankton station (Stn 1301) was located in the Atlantic domain, where the upper 500 to $600 \mathrm{~m}$ was dominated by AW, overlying AIW (Fig. 2). Below $1000 \mathrm{~m}$, Norwegian Sea Deep Water (NSDW) prevailed (not shown in the figure). Crossing the Arctic front, surface water salinity and temperature decreased (Fig. 2). Stns 1308, 1312, 1315 and 1318 were all located in the Arctic domain where the upper 200 to $300 \mathrm{~m}$ was AIW. This water mass overlays the Greenland and Norwegian Sea Deep Water (GSDW, NSDW), with salinity between 34.88 and 34.94 and temperature below $0^{\circ} \mathrm{C}$ (Fig. 2). After Stn 1318, the Arctic front was crossed a second time, returning to the Atlantic domain. Stn 1327 was located in its periphery with AW confined to the upper $150 \mathrm{~m}$.

\section{Calanus spp.}

Abundance and stage composition

With the exception of the western most station, the abundance of Calanus finmarchicus was highest in the Atlantic domain. The highest number $\left(\sim 35000 \mathrm{~m}^{-2}\right)$ was recorded at the southern most station (Stn 1327) (Table 1). C. hyperboreus had its highest abundance in the Arctic domain ( $\max \sim 2600 \mathrm{~m}^{-2}$ ), but was always less abundant than $C$. finmarchicus in the upper $1000 \mathrm{~m}$. C. glacialis was registered only in very low numbers ( $\max 400 \mathrm{~m}^{-2}$ ) in the Arctic domain, and will therefore not be discussed further (Table 1).

Only stage CIV, CV and adults of Calanus spp. were found. The stage composition changed somewhat in concert with change of water mass. C. finmarchicus overwintered mainly as CIV and CV. CV was the most common stage in the Atlantic domain, while the proportion of CIV increased in the Arctic domain, reaching a maximum of $61 \%$. Males were absent at all stations (Table 1). For C. hyperboreus, CV was the dominant overwintering stage throughout the survey area (Table 1). There was a decrease in the proportion of females in the colder and less saline water masses. Males were encountered only in the Arctic domain (Table 1).

\section{Vertical distribution}

Calanus finmarchicus was distributed deepest in the Atlantic domain, where the population bulk was centred below the AW (Fig. 2). WMD became shallower for all stages when moving into the Arctic domain. With one exception, CIV resided considerably deeper than CV and adult females (Fig. 2). C. finmarchicus seemed to be more homogeneously distributed with depth in the Arctic domain. C. hyperboreus overwintered deeper than $C$. finmarchicus, and the population bulk was always confined to strata below $400 \mathrm{~m}$. No pronounced vertical segregation between the different stages of $C$. hyperboreus was observed (Fig. 2).

\section{Abundance and vertical distribution of potential predators}

\section{Invertebrates from the net tows}

Chaetognaths were the most abundant invertebrate predator, with maximum numbers of about $1200 \mathrm{~m}^{-2}$ at the western most station (Table 1). Abundance was fairly similar at both sides of the Arctic front. No 

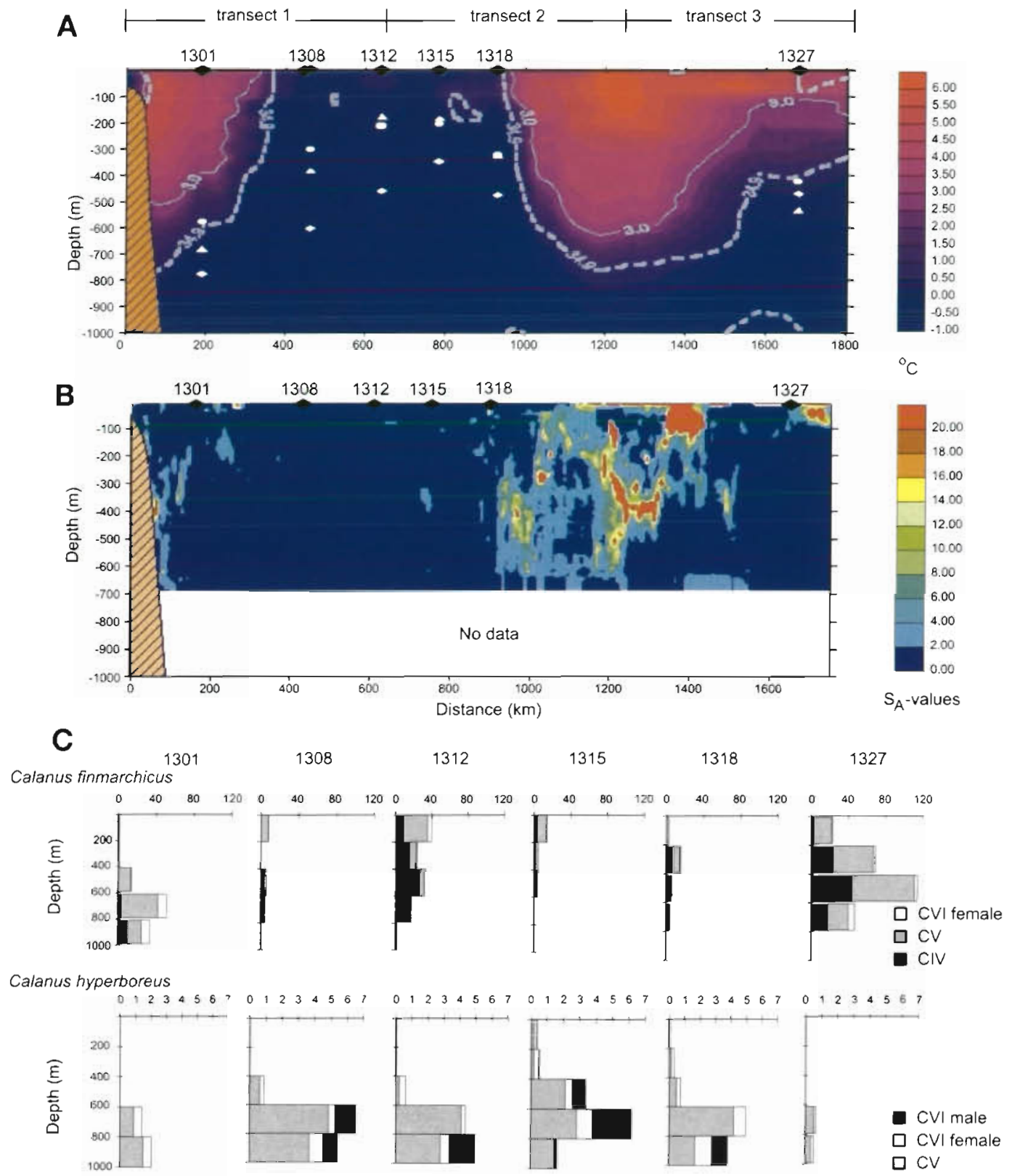

Invertebrate predators

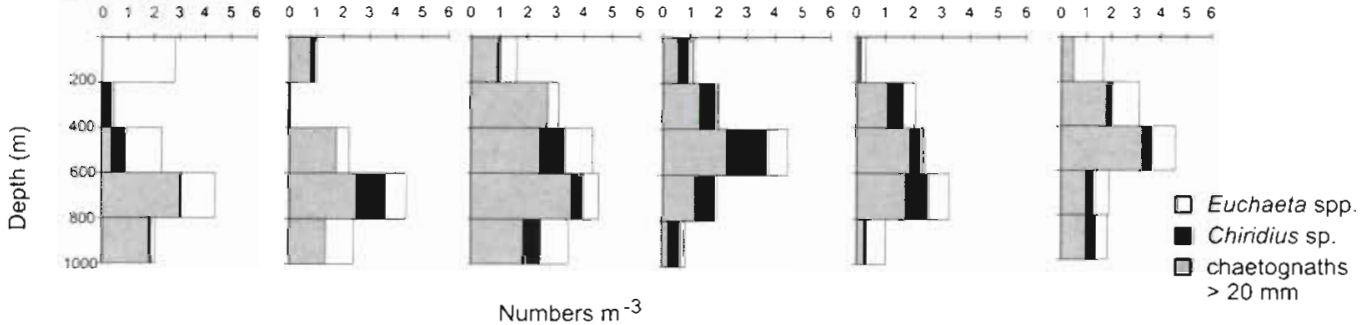

Fig. 2. (A) Isoplot of temperature along the cruise track. The 34.9 isohaline (dotted line) and WMD (Weighted Mean Depth) for Calanus finmarchicus are superimposed. ( $\left(\right.$ ) CIV, (O) CV, () CVI females. (B) Acoustic area backscattering $\left(\mathrm{m}^{-2} \mathrm{~nm}^{-2}\right)$ versus depth along the cruise track. Colour scale refers to level of area backscattering ( $S_{A}$, Knudsen 1990, Foote et al. 1991). For both temperature and area backscattering, transect numbers and station locations are denoted on top and correspond to those displayed in Fig. 1 (C) Stage and species specific vertical distribution of C. finmarchicus, C. hyperboreus and invertebrate predators in the upper $1000 \mathrm{~m}$ 
Table 1. Abundance and stage (size) composition for each species (\%) of 3 herbivorous copepods, 2 carnivorous copepods and chaetognaths

\begin{tabular}{|c|c|c|c|c|c|c|c|c|c|c|c|c|}
\hline \multirow[t]{2}{*}{ Station } & \multicolumn{2}{|c|}{1301} & \multicolumn{2}{|c|}{1308} & \multicolumn{2}{|c|}{1312} & \multicolumn{2}{|c|}{1315} & \multicolumn{2}{|c|}{1318} & \multicolumn{2}{|c|}{1327} \\
\hline & $n \mathrm{~m}^{-2}$ & $\%$ & $n m^{-2}$ & $\%$ & $n m^{-2}$ & $\%$ & $n m^{-2}$ & $\%$ & $n m^{-2}$ & $\%$ & $n m^{-2}$ & $\%$ \\
\hline Calanus finmarchicus CIV & 2932 & 1.4 .6 & 1608 & 38.6 & 14072 & 61.1 & 2148 & 43.5 & 3528 & 56.8 & 13180 & 35.8 \\
\hline Calanus finmarchicus CV & 13440 & 67.1 & 2344 & 56.2 & 7716 & 33.5 & 2572 & 52.1 & 2452 & 39.5 & 21380 & 58.0 \\
\hline Calanus finmarchicus female & 3676 & 18.3 & 216 & 5.2 & 1248 & 5.4 & 220 & 4.5 & 232 & 3.7 & 2300 & 6.2 \\
\hline Total & 20048 & & 4168 & & 23036 & & 4940 & & 6212 & & 36860 & \\
\hline Calanus hyperboreus CV & 484 & 69.1 & 1832 & 70.7 & 1416 & 70.7 & 1344 & 55.5 & 1292 & 65.5 & 184 & 75.4 \\
\hline Calanus hyperboreus female & 216 & 30.9 & 312 & 12.0 & 260 & 13.0 & 372 & 15.4 & 476 & 24.1 & 60 & 24.6 \\
\hline Calanus hyperboreus male & & 0.0 & 448 & 17.3 & 328 & 16.4 & 704 & 29.1 & 204 & 10.3 & & 0.0 \\
\hline Total & 700 & & 2592 & & 2004 & & 2420 & & 1972 & & 244 & \\
\hline Calanus glacialis CIV & & & 68 & 77.3 & 100 & 100.0 & 40 & 100.0 & 396 & 99.0 & & \\
\hline Calanus glacialis CV & & & 20 & 22.7 & 0 & 0.0 & 0 & 0.0 & 4 & 1.0 & & \\
\hline Total & & & 88 & & 100 & & 40 & & 400 & & & \\
\hline Euchaeta sp. CIV & 32 & 11.3 & 12 & 10.3 & 20 & 11.6 & 20 & 23.8 & 28 & 28.0 & 20 & 9.8 \\
\hline Euchaeta sp. CV & 108 & 38.0 & 36 & 31.0 & 24 & 14.0 & 32 & 38.1 & 28 & 28.0 & 72 & 35.3 \\
\hline Euchaeta sp. CVI female & 132 & 46.5 & 64 & 55.2 & 120 & 69.8 & 32 & 38.1 & 36 & 36.0 & 96 & 47.1 \\
\hline Euchaeta sp. CVI male & 12 & 4.2 & 4 & 3.5 & 8 & 4.7 & 0 & 0.0 & 8 & 8.0 & 16 & 7.8 \\
\hline Total & 284 & & 116 & & 172 & & 84 & & 100 & & 204 & \\
\hline Chiridius sp. juveniles & 20 & 35.7 & 32 & 47.1 & 56 & 56.0 & 104 & 59.1 & 56 & 58.3 & 8 & 11.1 \\
\hline Chiridius sp. female & 36 & 64.3 & 36 & 52.9 & 44 & 44.0 & 72 & 40.9 & 36 & 37.5 & 64 & 88.9 \\
\hline Chiridius sp. male & 0 & 0.0 & 0 & 0.0 & 0 & 0.0 & 0 & 0.0 & 4 & 4.2 & 0 & 0.0 \\
\hline Total & 56 & & 68 & & 100 & & 176 & & 96 & & 72 & \\
\hline Chaetognaths $<20 \mathrm{~mm}$ & 132 & 33.3 & 220 & 40.4 & 600 & 50.8 & 140 & 33.0 & 435 & 62.6 & 300 & 43.9 \\
\hline Chaetognaths $>20 \mathrm{~mm}$ & 264 & 66.7 & 324 & 59.6 & 580 & 49.2 & 284 & 67.0 & 260 & 37.4 & 384 & 56.1 \\
\hline Total & 396 & & 544 & & 1180 & & 424 & & 696 & & 684 & \\
\hline
\end{tabular}

marked difference in size distribution between the 2 domains was found (Table 1). Chaetognath distributions overlapped with those of Calanus finmarchicus (Fig. 2), and small individuals $(<20 \mathrm{~mm})$ were distributed shallower than large (>20 $\mathrm{mm}$ ).

Euchaeta spp. followed the same horizontal distributional pattern as Calanus finmarchicus, being most abundant at the western most station and at stations in the Atlantic domain (Table 1). CV and adult females were the dominant stages irrespective of water masses. Euchaeta spp. generally occupied shallower waters in the Atlantic domain than on the Arctic side of the front, but there were considerable differences between stations within the same domain. The youngest stages were found deeper than the older.

Chiridius sp. was less abundant than Euchaeta spp., and both its horizontal and vertical distribution appeared to be independent of water mass (Fig. 2, Table 1). Juveniles and females occurred at all stations, whereas males were only present at one station. Adult females were the most abundant stage in the Atlantic domain, while their proportion decreased somewhat in the Arctic domain.

\section{Acoustic records}

The level of area backscattering changed markedly along the cruise track, apparently being tightly coupled to the distribution of water masses (Fig. 2). High backscattering was confined to the AW close to the Barents Sea shelf (start of Transect 1) and in the central Norwegian Sea (end of Transect 2, Transect 3). High backscattering was normally restricted to waters above $500 \mathrm{~m}$, and was most shallowly distributed at the end of Transect 3 (Fig. 2), where AW constituted a relatively shallow layer (Fig. 2). The AIW and the underlying GSDW of the north western part of the transect (end of Transect 1, first part of Transect 2) were almost devoid of backscattering (Fig. 2).

\section{DISCUSSION}

Calanus finmarchicus was the most abundant larger copepod of the upper $1000 \mathrm{~m}$ in both Arctic and Atlantic waters, but seemed to have a regional preference towards the Atlantic domain. This is in accordance with Hirche (1991) and Richter (1994). C. hyper- 
boreus was most abundant in the Greenland Sea Gyre, where Hirche (1991) suggests that it has one of its centres of occurrence. Catches of $C$. hyperboreus were nevertheless low at all stations, probably due to the lack of sampling deeper than $1000 \mathrm{~m}$. This is indicated by the shape of the vertical distributions (Fig. 2), and further by earlier investigations showing that the bulk of the $C$. hyperboreus population overwinters below 1000 metres in both the Norwegian and Greenland Sea (Østvedt 1955, Hirche 1991, Richter 1994, 1995). C. glacialis occurred only in the Arctic domain, and then in very low numbers. This species seems to be rare in this part of the Greenland Sea (cf. Jaschnov 1970 , Hirche 1991, Richter 1994).

The population stage structure of Calanus finmarchicus was more advanced in the Atlantic than in the Arctic domain. The stage composition was fairly similar to that previously described from the Greenland (Hirche 1991, Richter 1994) and Norwegian Seas (Ostvedt 1955). Still, our results show a somewhat higher proportion of CIV than previously described from more central parts of the Atlantic domain (Østvedt 1955). The absence of males is characteristic for periods prior to the breeding season (Sømme 1934, Conover 1965, Hirche 1991, Richter 1994). With the exception of the presence of males in the Arctic domain, the stage composition of $C$. hyperboreus was remarkably uniform in spite of differences in abundance, with $\mathrm{CV}$ being the dominant stage. This stage composition differed somewhat from those previously described in the Greenland and Norwegian Seas and in a Norwegian fjord (Østvedt 1955, Matthews et aI. 1978, Hirche 1991, Richter 1994, Hirche 1997), where stages CIV and CIII were far more prominent. However, lack of sampling deeper than $1000 \mathrm{~m}$ probably biased the results of this deep living species, as it is unlikely that sampling only the upper margin of the population provides a correct description of the entire stage distribution.

There was a vertical stage segregation of Calanus finmarchicus, where CrV inhabited somewhat deeper waters than CV and adults, which is in accordance with Hirche (1991) and Richter (1994). We cannot conclude whether this is adaptive, or has a purely physical explanation since CIV conceivably have accumulated less lipid than $\mathrm{CV}$ and adults and are therefore assumed to be less buoyant.

Calanus finmarchicus overwintered at considerably deeper depths in the Atlantic than in the Arctic domain. The temperature of the overwintering habitat was mainly between -0.5 and $0.5^{\circ} \mathrm{C}$ at both sides of the Arctic front, which resembles the results of Hirche (1991). Since respiration is temperature dependent, and essential energy stores last longer in cold water, temperature is an important feature of the overwinter- ing habitat. Temperature could therefore be a guiding cue for copepods in search for an adequate overwintering habitat.

Predator avoidance has become a widely accepted explanation for diel vertical migrations in zooplankton. This particularly relates to visual predators (Gliwicz 1986, Frost 1988, Bollens \& Frost 1991, Bollens et al. 1992), but also invertebrates may influence both abundance (e.g. Ohman et al. 1983, Yen 1983, Feigenbaum \& Maris 1984, Øresland 1990) and vertical distribution patterns (e.g. Ohman et al. 1983, Neill 1990, 1992, Frost \& Bollens 1992) of their prey. Likewise, predator avoidance might be a driving force for Calanus finmarchicus in the selection of a suitable overwintering habitat (Kaartvedt 1996).

Since many invertebrate predators do not depend on light for hunting, deep dark habitats do not provide an absolute refuge for overwintering Calanus. However, vertical dispersion as observed in this and in previous investigations, along with inactivity, may reduce the probability of encounter with invertebrate predators and therefore be adaptive.

Chaetognaths are believed to be important predators on copepods (see Feigenbaum \& Maris 1984), with a diet often reflecting the zooplankton available (Pearre 1973, Sullivan 1980). Chaetognaths can utilise prey of a wide spectrum of sizes (Pearre 1980), and though feeding rates are low (Sameoto 1987, Falkenhaug 1991, Oresland 1995) the cumulative predation on non-reproducing prey during winter may be significant for the population size (Øresland 1995). Copepods of the family Euchaetidae mainly feed on smaller copepods (Lowdnes 1935, Shuert \& Hopkins 1987. Øresland 1990, Yen 1991, Øresland \& Ward 1993), but Euchaeta norvegica might still be an important predator on diapausing Calanus finmarchicus (Bathmann et al. 1990). E. norvegica is the most common species of Euchaeta in the North Atlantic (Park 1995). The feeding preferences of the larger E. glacialis have not been studied. Chiridius sp. is an omnivore (Arashkevich 1969, Alvarez \& Matthews 1975) which primarily feeds on small copepods, ciliates, and possibly detritus (Ottesen 1995). Chiridius sp. does not appear to feed efficiently on larger copepads (Alvarez \& Matthews 1975). Considered along with its low abundance, Chiridius $\mathrm{sp}$. was not likely to be an important predator on overwintering $C$. finmarchicus.

The distributions of the studied invertebrate predators did not provide any apparent explanation for the varying overwintering distributions of Calanus finmarchicus. Chaetognaths were the most abundant invertebrate predators, and their vertical distributions largely overlapped with those of C. finmarchicus regardless of water mass. The distributions of Euchaeta spp., a mixture of E. norvegica and E. glacialis, and 
Chiridius sp. varied in an unsystematic pattern but did generally overlap with those of $C$. finmarchius. In the study of Noji \& Noji (1991) both chaetognaths and Euchaeta spp. were particularly abundant at the overwintering depths of $C$. finmarchicus. Because potentially important predators such as krill, amphipods and other large and highly mobile invertebrates probably avoid the MULTINET to a large extent (Melle et al. 1993, Sameoto et al. 1993), their potential impact is not evaluated.

The compressed echo plots may reflect the large scale distribution of planktivorous fish, and thereby roughly visualise the predatory regime encountered by the zooplankton. There was a conspicuous coupling between the level of acoustic backscattering and the type of water mass. In the Arctic domain, where Calanus finmarchicus overwintered at a relatively shallow depth, the backscattering was very low. Although the acoustic records reveal that few planktivorous fish were present in the Arctic domain during winter, seasonally occurring herring feeding on Calanus may be abundant (Kaartvedt unpubl, results) during the period when $C$. finmarchicus starts to descend in summer. The possible presence of fish predators during summer may explain why Calanus in this area descends at all.

The highest levels of acoustic backscattering were registered in the Atlantic domain, being more or less confined to the AW layer. Calanus finmarchicus was centred below the sound scattering layers (SSLs), deepest in the eastern parts, and with its overwintering depth decreasing as the SSL became shallower and weaker. Due to bad weather, zooplankton samples were not obtained from the central Atlantic domain. However, several other investigations in this particular area show that overwintering $C$. finmarchicus 'avoids' the Atlantic water masses, with the population bulk residing below about $600 \mathrm{~m}$ (Østvedt 1955, Noji 1989. Bathmann et al. 1990, Hirche 1991). Earlier studies have revealed that Atlantic water masses closer to the Norwegian shelf share the same acoustic characteristics as observed in the AW in our study (Melle et al. 1993, Torgersen et al. 1997). In the eastern part of the North Atlantic the mesopelagic planktivorous fish Maurolicus muelleri is generally responsible for SSLs between 100 to $200 \mathrm{~m}$ during daytime (Melle et al. 1993, Kaartvedt et al. 1996, Torgersen et al. 1997), while the planktivorous mesopelagic fish Benthosema glaciale is a major constituent of SSLs between 300 to $500 \mathrm{~m}$ by day, a layer which can also hold krill and pelagic shrimps (Melle et al. 1993). Both these fishes are potentially strong predators on Calanus (e.g. Gjøsæter 1973, 1981, Sameoto 1988, 1989). During our investigation, no trawling was undertaken, so the components of the SSLs were not identified. Nevertheless, the acoustic characteristics, distributions and indications of diel vertical migration patterns, suggest a composition corresponding fairly well with previous investigations. In any case, the acoustic records document that the distribution of organisms larger than several centimetres (which would often be predators on Calanus) follows the distribution of water masses.

Since the potential predation pressure represented by acoustic backscattering co-varied strongly with temperature, we cannot isolate the potential effect of these 2 factors on Calanus' choice of overwintering depth.

In this context, it is interesting to compare Calanus overwintering with the overwintering of Antarctic copepods, also performing seasonal vertical migrations. Several Antarctic species descend for overwintering between 500 and $1000 \mathrm{~m}$. Data by Spiridonov \& Kosobokova (1997) show copepods actually descending into warmer waters. Thus, choice of overwintering habitat based on energy conservation does not apply in this case. As in the North Atlantic, myctophid mesopelagic fishes may be very abundant in Antarctic waters (Lancraft et al. 1989, 1991), and are believed to feed largely on copepods (Rodhouse \& White 1995. Pakhomov et al. 1996).

In conclusion, predatory avoidance appears to be a valid alternative to temperature preference explaining the different overwintering depths of Calanus observed in the different water masses in the Norwegian and Greenland Seas.

Acknowledgements. We thank Tor Knutsen for assistance with the BEI database and Johan Blindheim for access to the CTD data. This is a contribution from TASC (Trans Atlantic Study of Calanus finmarchicus) funded by the European Commission Contract No. MAS3-CT95-0039.

\section{LITERATURE CITED}

Alvarez V, Matthews JBL (1975) Experimental studies on the deep-water pelagic community of Korsfjorden. Western Norway. Feeding and assimilation by Chiridius armatus (Crustacea, Copepoda). Sarsia 58:67-78

Arashkevich YC (1969) The food and feeding of copepods in the northwestern Pacific. Oceanol Acad Sci USSR 9: 695-709

Bathmann UV, Noji TT, von Bodungen B (1990) Copepod grazing potential in late winter in the Norwegian Sea-a factor in the control of spring phytoplankton growth? Mar Ecol Prog Ser 60:225-233

Bollens SM, Frost BW (1991) Diel vertical migration in zooplankton: rapid individual response to predators. J Plankton Res 13:359-1365

Bollens SM, Frost BW, Thoreson DS, Watts SJ (1992) Diel vertical migration of zooplankton: field evidence in support of the predator avoidance hypothesis. Hydrobiologia 243: $33-39$

Conover RJ (1965) Notes on the moulting cycle, development of sexual characters and sex ratio in Calanus hyperboreus. Crustaceana 13:61-72 
Conover RJ (1988) Comparative life histories in the genera Calanus and Neocalanus in high latitudes of the northern hemisphere. Hydrobiologia 167/168:127-142

Falkenhaug $\mathrm{T}$ (1991) Prey composition and feeding rate of Sagitta elegens var arctica (Chaetognatha) in the Barents Sea in early summer. Polar Res 10:487-506

Feigenbaum DK, Maris RC (1984) Feeding in Chaetognatha Oceanogr Mar Biol Annu Rev 22:343-392

Foote KG, Knudsen HP, Korneliussen RJ, Nordbø PE, Røang K (1991) Postprocessing system for echo sounder data. J Acoust Soc Am 90:37-38

Frost BW (1988) Variability and possible adaptive significance of diel vertical migration in Calanus pacificus, a planktonic marine copepod. Bull Mar Sci 43:675-694

Frost BW, Bollens SM (1992) Variability of diel vertical migration in the marine planktonic copepod Pseudocalanus newmani in relation to its predators. Can J Fish Aquat Sci 49:1137-1141

Gjøsæter J (1973) The food of the myctophid fish, Benthosema glaciale (Reinhardt), from western Norway. Sarsia $52: 53-58$

Gjøsæter J (1981) Life history and ecology of Maurolicus muelleri (Gonostomidae) in Norwegian waters. Fiskeridir Skr Ser Havunders 17:109-131

Gliwicz MZ (1986) Predation and the evolution of vertical migration in zooplankton. Nature 320:746-748

Hairston NG Jr (1987) Diapause as a predator avoidance adaptation. In: Kerfoot WC, Sih A (eds) Predation: direct and indirect impacts. University Press of New England Hanover, p 281-290

Hirche HJ (1983) Overwintering of Calanus finmarchicus and Calanus helgolandicus. Mar Ecol Prog Ser 11:281-290

Hirche HJ (1991) Distribution of dominant calanoid copepod species in the Greenland Sea during late fall. Polar Biol $11: 351-362$

Hirche HJ (1997) Life cycle of the copepod Calanus hyperboreus in the Greenland Sea. Mar Biol 128:607-618

Hirche HJ, Hagen W, Mumm N, Richter C (1994) The Northeast Water Polynya, Greenland Sea. III. Meso- and macrozooplankton distribution and production of dominant herbivorous copepods during spring. Polar Biol 11:351-362

Jaschnov WA (1970) Distribution of Calanus species in the seas of the northern hemisphere. Int Rev Ges Hydrobiol 55:197-212

Kaartvedt S (1996) Habitat preference during overwintering and timing of seasonal vertical migrations of Calanus finmarchicus. Ophelia 44:145-156

Knudsen HP (1990) The Bergen Echo Integrator: an introduction. J Cons Int Explor Mer 47:167-174

Lancraft TM, Torres JJ, Hopkins TL (1989) Micronecton and macrozooplankton in the open waters near Antarctic ice edge zones (AMIREZ 1983 and 1986). Polar Biol 9:225-233

Lancraft TM, Hopkins TL, Torres JJ, Donnelly J (1991) Oceanic micronecton/macrozooplanktonic community structure and feeding in ice covered Antarctic waters during the winter (AMIREZ 1988). Polar Biol 11:157-167

Lowdnes AG (1935) The swimming and feeding of certain calanoid copepods. Proc Zool Soc Lond 687-715

Marshall SM, Orr PA (1955) The biology of a marine copepod Calanus finmarchicus Gunnerus. Oliver \& Boyd, Edinburgh

Matthews JBL, Hestad L, Bakke JLW (1978) Ecological studies in Korsfjorden western Norway. The generations and stocks of Calanus hyperboreus, Calanus finmarchicus in 1971-1974. Oceanol Acta 1:277-284

Melle W, Kaartvedt S, Knutsen T, Dalpadado P, Skjoldal HR (1993) Acoustic visualisation of large scale macroplankton and micronecton distributions across the Norwegian shelf and slope of the Norwegian Sea. ICES Comm Meet 1993/L:44:1-25

Miller CB, Cowles TJ, Weibe PH, Copley NC, Grigg H (1991) Phenology in Calanus finmarchicus; hypotheses about control mechanisms. Mar Ecol Prog Ser 72:79-91

Neill WE (1990) Induced vertical migration in copepods as a defence against invertebrate predation. Nature 345:524-526

Neill WE (1992) Population variation in the ontogeny of predator-induced vertical migration of copepods. Nature 356:524-526

Noji TT (1989) The influence of zooplankton on sedimentation in the Norwegian Sea. Ber Sonderforschungbereich 313, Univ Kiel 17:1-183

Noji TT, Noji CIM (1991) Biologiske forhold på Vøringsplatået: Forprosjekt innen AKUPs utredningsprogram. Havforskningsinstituttets rapporter 11(2):1-17

Ohman MD (1988) Behavioural responses of zooplankton to predation. Bull Mar Sci 43:530-550

Ohman MD, Frost BW, Cohen EB (1983) Reverse diel migration: an escape from invertebrate predators. Science 220: $1404-1407$

Øresland V (1990) Feeding and predation impact of the chaetognath Eukrohnia hamata in Gerlache Strait, Antarctic Peninsula. Mar Ecol Prog Ser 63:201-209

$\varnothing$ resland V (1995) Winter population structure and feeding of the chaetognath Eukrohnia hamata and the copepod Euchaeta antarctica in Gerlache Strait, Antarctic Peninsula. Mar Ecol Prog Ser 119:77-86

Øresland V, Ward P (1993) Summer and winter diet of four carnivorous copepod species around South Georgia. Mar Ecol Prog Ser 98:73-78

Østvedt OJ (1955) Zooplankton investigations from weathership $M$ in the Norwegian Sea, 1948-49. Hvalrådets Skr 40: $1-93$

Ottesen GO (1995) Næringsøkologi hos to predaterende kopepoder, Chiridius armatus (Boeck) og Euchaeta norwegica (Boeck) i nordnorske farvann. Cand. scient. thesis, Norwegian College of Fishery Science, Univ Tromsø

Pakhomov EA, Perissinotto R, McQuaid CD (1996) Prey composition and daily rations of myctophid fishes in the Southern Ocean. Mar Ecol Prog Ser 134:1-14

Park $T$ (1995) Taxonomy and distribution of the marine calanoid copepod family Euchaetidae. Bull Scripps Instn Oceanogr 29:1-107

Pearre S JI (1973) Vertical migration and feeding in Sagitta elegans Verrill. Ecology 54:300-314

Pearre S Jr (1980) Feeding by Chaetognatha: the relation of prey size to predator size in several species. Mar Ecol Prog Ser 3:125-134

Richter C (1994) Regional and seasonal variability in the vertical distribution of mesozooplankton in the Greenland Sea. Ber Polarforsch 154:1-80

Richter C (1995) Seasonal changes in the vertical distribution of mesozooplankton in the Greenland Sea Gyre $\left(75^{\circ} \mathrm{N}\right)$ : distribution strategies of calanoid copepods. ICES J Mar Sci 52:533-539

Rodhouse PG. White MG (1995) Cephalopods occupy the ecological niche of epipelagic fish in the Antarctic polar frontal zone. Biol Bull (Woods Hole) 189:77-80

Sameoto DD (1987) Vertical distribution and ecological significance of chaetognaths in the arctic environment of Baffin Bay. Polar Biol 7:317-328

Sameoto DD (1988) Feeding of lanternfish Benthosema glaciale off the Nova Scotia shelf. Mar Ecol Prog Ser 44:113-129

Sameoto DD (1989) Feeding ecology of the lanternfish Benthosema glaciale in a subarctic region. Polar Biol 9:169-178 
Sameoto DD, Cochrane NA, Herman AW (1993) Convergence of acoustic, optical, and net-catch estimates of euphausiid abundance: use of artificial light to reduce net avoidance. Can J Fish Aquat Sci 50:334-346

Shuert PG, Hopkins TL (1987) The vertical distribution and feeding ecology of Euchaeta marina in the eastern gulf of Mexico. Contr Mar Sci 30:49-61

Somme J (1934) Animal plankton of the Norwegian coast waters and the open sea. I. Production of Calanus finmarchicus (Gunnerus) and Calanus hyperboreus (Krøyer) in the Lofoten area. Fiskesridir Skr Ser Havunders 4:1-163

Spiridonov WA, Kosobokova KN (1997) Winter ontogenetic migrations and the onset of gonad development in large dominant calanoid copepods in Weddell Gyre (Antarctica). Mar Ecol Prog Ser 157:233-246

Stefánsson U (1962) North Icelandic waters. Rit Fiskideildar 3:1-269

Sullivan BK (1980) In situ feeding behaviour of Sagitta elegans and Eukronhia hamata (Chaetognatha) in relation to the vertical distribution and abundance of prey at Ocean Station ' $P$ '. Limnol Oceanogr 25:317-326

Swift JH (1986) The Arctic waters. In: Burton GH (ed) The Nordic Seas. Springer, New York, p 129-153

Editorial responsibility: Otto Kinne (Editor),

Oldendorf/Luhe, Germany
Tande KS (1982) Ecological investigations on the zooplankton community of Balsfjorden, northern Norway: general cycles, and variation in body weight and body content of carbon and nitrogen related to overwintering and reproduction in the copepod Calanus finmarchicus (Gunnerus). $J$ Exp Mar Biol Ecol 62:129-142

Tande KS, Hopkins CCE (1981) Ecological investigations on the zooplankton community of Balsfjorden, northern Norway: the genital system in Calanus finmarchicus and the role of gonad development in overwintering strategy. Mar Biol 63:159-164

Torgersen T, Kaartvedt S, Melle W, Knutsen T (1997) Large scale distribution of acoustic scattering layers at the Norwegian continental shelf and the eastern Norwegian Sea. Sarsia 82:87-96

Undstad KH, Tande K (1991) Depth distribution of Calanus finmarchicus and C. glacialis in relation to environmental conditions in the Barents Sea. Polar Res 10:409-420

Yen J (1983) Effects of prey concentration, prey size, predator life stage, predator starvation, and season on predation rates of the carnivorous copepod Euchaeta elongata. Mar Bial 75:69-77

Yen J (1991) Predatory feeding behavior of an Antarctic marine copepod, Euchaeta antarctica. Polar Res 10:433-442

Submitted: April 27, 1998; Accepted:December 2, 1998 Proofs received from author(s): March 23, 1999 